\title{
School Mediation Programmes and Incidents of In-School Violence and Bullying
}

\author{
“Konstantinos Karakiozis: Youth Counseling Station of Western Attica, Greece. \\ Evangelos C. Papakitsos: School of Pedagogical and Technological Education, Greece.
}

\begin{abstract}
School mediation (or peer mediation) is an effective practice for dealing with cases of in-school violence and bullying. According to the results of this retrospective research, conducted in High-Schools of the Municipality of Fyli (Athens metropolitan area, Greece), school mediation programmes contribute to: activating students wishing to help their classmates, taking responsibility and developing social/communication skills of the students involved. At the same time, it is important to point out the substantial gender differentiation in attitudes both towards incidents of in-school violence and bullying, but also to school mediation programmes. Finally, the positive response of students, who participate voluntarily beyond ordinary school hours in these programmes, is a demand for a school that responds to students' needs.
\end{abstract}

Key words: School mediation, Peer mediation, In-school violence, Bullying.

1. Introduction

Conflicts between students are an everyday activity in schools and exist in every educational system (Galanaki, 2010; Panousis, 2011; Rigby, 2008). Many times however, these conflicts go beyond certain boundaries by acquiring characteristics of in-school violence and bullying. In order to deal with these incidents, schools implement a series of programmes or actions (Farrington \& Ttofi, 2009; Karakiozis, Papapanousi, Mavrakis, \& Papakitsos, 2015b; Olweus, 1997; Olweus., 2005; Rigby, 2008; Rigby., 2012) including school mediation (or peer mediation).

A particular behaviour has characteristics of in-school violence and bullying when it is aggressive or deliberate, occurs "repeatedly for some time" and is characterized by an "imbalance in power", an "asymmetrical power relationship", where a student cannot defend himself/herself (Olweus.. 2009). On the other hand, it is not considered in-school violence and bullying when (Olweus, 1997):

- There is a conflict between people of similar physical or mental power,

International Journal of

2018

DOI: $10.53935 / 2641-533 x . v 1 i 2.79$

Corresponding Author: Konstantinos

Karakiozis

Funding: This study received no specific

financial support.

Article History:

Received: 24 April 2018

Revised: 26 September 2018

Accepted: 15 November 2018

Published: 21 December 2018

(C) 2018 by the authors; licensee Academic Publishing Group

- There is teasing between peers and

- There is a playful or friendly mood.

School mediation is defined as a "peaceful resolution of a conflict in school life, between two or more disagreeing students with the help of a third and neutral student - the mediator - through a structured process with clear boundaries, active participation and direct contact between the parties, and with the purpose of a constructive resolution of the dispute" (Artinopoulou, 2010).

School mediation programmes have been implemented internationally since the 1960s, initially as a result of peace movements (Johnson \& Johnson, 1996), as a reaction to traditional/authoritarian forms of 
intervention (Rigby., 2012) and alternatively to the dominant disciplinary system, based on punishment (Artinopoulou, 2010). In general, they constitute a successful intervention in primary and secondary schools(Artinopoulou, 2010; Association for Conflict Resolution Education Section, 2007; Bitel \& Rolls, 2000; Burrell, Zirbel, \& Allen, 2003; Center for European Constitutional Law, 2015; Cremin, 2007; Haynes, Haynes, \& Fong, 2004; Johnson \& Johnson, 1996; Liebmann, 2000; Stitt, 2004; U.S. Department of Justice, 2000) with positive results for both the participants and the school. Benefits of course vary according to the degree of implementation of each programme (Bickmore, 2002).

In Greece, school mediation programmes have been implemented over the last ten years (Health Education Programmes), beyond ordinary school hours in Secondary Education, with the voluntary participation of students and teachers.

\section{Research Purpose and Questions}

The purpose of this research is to investigate the attitudes of students of the High-Schools in the Municipality of Fyli (Athens metropolitan area, Greece), who participate in a school mediation programme against incidents of in- school violence and bullying, with the ultimate goal of critically evaluating these programs.

In particular, the following research questions were raised:

i. Are the attitudes of students, involved in a school mediation programme relevant to incidents of inschool violence and bullying, related to the attitudes of their peers, who are not participating in a similar program?

ii. Are the attitudes of students, involved in a school mediation programme about the role of third parties (adults or classmates) in relation to instances of in-school violence and bullying, correlated with the attitudes of their peers who are not participating in a similar program?

iii. How do the participating students evaluate the school mediation programme implemented at their school?

iv. Do the attitudes of students vary according to gender?

\section{Research Methodology}

This study was carried out in schools of the Municipality of Fyli (Athens metropolitan area, Greece), a region with particular social, economic and environmental characteristics that have a decisive impact on the daily routine of school societies and the educational process itself (Papavasileiou \& Mavrakis, 2013). Indicatively, they are highlighted (General Census, 2011; Observatory, 2017; Peripheral Unity of Western Attica, 2015; Salvati \& Mavrakis, 2014): high unemployment rates, the existence of a large number of vulnerable social groups (such as Roma, immigrants and large families), the low educational level of the adult population, higher school dropout rates, increased criminality and the particular environmental burden of the area due to the waste management landfills that are located there.

The research planning followed has retrospective research features (Cohen \& Manion, 1994) to the extent that the independent variables are studied retrospectively to investigate possible relationships with the dependent variables. The participants were initially informed about the purpose, the process of the investigation and the confidentiality of the process. Quantitative data was firstly gathered through a closedended structured questionnaire, which was handed out to students of the three schools implementing a school mediation programme. Then a qualitative research was carried out, the results of which are being processed.

In order to select the sample of quantitative research, layer sampling was used (Creswell, 2011) for the selection of schools and mediation groups, as well as random sampling for the selection of non-participating to mediation programme students. Specifically, 110 students, being 60 girls (54.5\%) and 50 boys (45.5\%), participated. From the respondents, 61 (55.5\%) were involved in a school mediation program (28 boys and 33 girls) and $49(44.5 \%)$ did not participate ( 22 boys and 27 girls). The students of the sample were studying in the three grades of lower high-school (Gymnasium), especially in the 1st grade 33 students (30\% of the total), 2nd grade 45 (41\% of the total) and 3rd grade 32 (29\% of the total). Similarly in the sample, $45 \%$ of students of the 1 st grade, $49 \%$ of the 2 nd grade and $38 \%$ of students of the 3rd grade participated in a school mediation programme.

With regard to family status, $63.6 \%$ of students having one or more siblings and $16.4 \%$ living in an extended family (parents, siblings and grandparents) are not differentiated from participation in a mediation

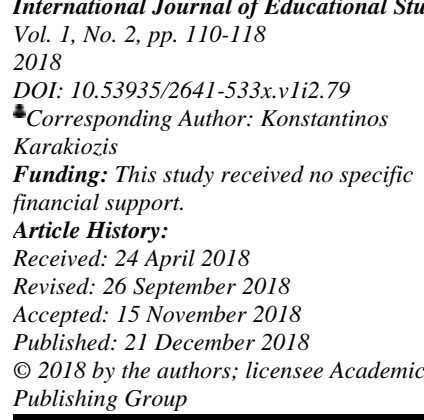


programme. Instead, double the percentage of students from single-parent families participates in a school mediation programme ( $8.2 \%$ vs. $4.1 \%$ of non-attendees). For single-child families, the corresponding rate is $11.5 \%$ and $16.3 \%$ for those who do not participate in a school mediation programme.

The revised version of the Olweus Bully Victim Questionnaire (OBVQ) was used to collect the data, which was modified to better cover the purpose and the data of the particular project. This questionnaire (OBVQ):

- $\quad$ has been used internationally in a large number of surveys (Bauer, Lozano, \& Rivara, 2007; Black \& Jackson, 2007; Gollwitzer, Eisenbach, Atria, Strohmeier, \& Banse, 2006; Katsigianni, 2006; Olweus, 1997; Olweus., 2005).

- $\quad$ has provided similar results in a previous survey with a corresponding population (Karakiozis, Papapanousi, Papakitsos, \& Argyriou, 2015a);

- $\quad$ has content validity (Kyriakides, Kaloyirou, \& Lindsay, 2006) and high internal consistency (Bauer et al., 2007; Black \& Jackson, 2007; Kyriakides et al., 2006; Olweus, 1997; Olweus., 2005; Pellegrini, 2001; Solberg \& Olweus, 2003).

In the present study, the Cronbach's alpha coefficient ranges between 0.79 and 0.94 , depending on the category of questions. At the same time, questions were added on the assessment of school mediation programmes, based on qualitative data from previous surveys (Artinopoulou, 2010; Giannatou, 2011).

\section{Results}

4.1. Attitudes towards School and Break

One of the first results of the survey was the very high percentage $(80.9 \%)$ of students who stated that they liked the break quite a lot (Table 1).

\begin{tabular}{llll}
\multicolumn{4}{c}{ Table-1. Students' attitude towards break. } \\
\hline Statement & Number of students & Percentage\% & Cumulative Frequency \% \\
\hline I do not like it at all & 2 & 1.8 & 1.8 \\
I do not like it that much & 1 & 0.9 & 2.7 \\
Neither like nor dislike it & 9 & 8.2 & 10.9 \\
I like it just a bit & 9 & 8.2 & 19.1 \\
I like it a lot & 89 & 80.9 & 100 \\
Totals & 110 & 100 & \\
\hline
\end{tabular}

On the contrary, in the corresponding questions about school, only $25.5 \%$ of the sample stated that they liked it a lot (Table 2).

\begin{tabular}{llll}
\hline \multicolumn{4}{c}{ Table- 2. Students' attitude towards school. } \\
\hline Statement & Number of students & Percentage\% & Cumulative Frequency \% \\
\hline I do not like it at all & 7 & 6.4 & 6.4 \\
I do not like it that much & 11 & 10.0 & 16.4 \\
Neither like nor dislike it & 16 & 14.5 & 30.9 \\
I like it just a bit & 48 & 43.6 & 74.5 \\
I like it a lot & 28 & 25.5 & 100 \\
Totals & 110 & 100 & \\
\hline
\end{tabular}

International Journal of Educational Studies Vol. 1, No. 2, pp. 110-118

2018

DOI: 10.53935/2641-533x.v1i2.79

Corresponding Author: Konstantinos

Karakiozis

Funding: This study received no specific

financial support.

Received: 24 April 2018

Revised: 26 September 2018

Accepted: 15 November 201

Published: 21 December 2018

(C) 2018 by the authors; licensee Academic

Publishing Group
To the question "How many good friends do you have in your class", $49.1 \%$ of the students stated that they have many good friends, $40 \%$ stated two or three good friends, $8.2 \%$ just one good friend and only $2.7 \%$ no good friend at all. There was also a moderately positive but statistically significant relationship $(\mathrm{r}=0.49, \mathrm{p}$ $=000, \mathrm{~N}=110$ ) between the number of friends that the students had in their class and how much did they like the break. Accordingly, there was a weak positive but statistically significant relationship between whether the students liked the break and whether they wanted to help in cases of in-school violence and bullying $(\mathrm{r}=$ $0.31, \mathrm{p}=001, \mathrm{~N}=110$ ). 


\subsection{Students Who Have Suffered or Exerted Bullying}

Initially, it should be noted that there was no statistically significant relationship between the participation of students in a school mediation programme and variables such as gender, classroom or family environment where they lived. Female students that participated in a school mediation programme have suffered bullying (in the last two months) by a lower percentage $(12.1 \%)$ than the non-participating ones $(18.5 \%)$. On the contrary regarding male students, the respective percentages were similar regardless of whether they participated or not in such a programme (17.9\% for those who participate and $18.2 \%$ for non-attendees). Also, $8.2 \%$ of students participating in a school mediation programme stated that they have suffered bullying by a girl/girls, compared to just $1.6 \%$ for those who did not participate in a programme.

A smaller percentage of male students, participating in a school mediation programme, have exerted bullying in the last two months $(14.3 \%)$ than non-attendees $(18.2 \%)$. For female students, the respective percentages were $6.1 \%$ and $7.4 \%$. These percentages also differ with respect to grade (15\% in 1 st grade, $7 \%$ in 2 nd grade and $13 \%$ in 3 rd grade).

There was a moderate positive correlation $(r=0.38, \mathrm{p}=000, \mathrm{~N}=110)$ between whether some students have suffered bullying and at the same time have exerted bullying themselves. In particular, half of the students $(50 \%)$ who have exerted bullying also stated that they have suffered bullying. Accordingly, one out of three students (33.3\%) from those who have suffered bullying stated at the same time that they have exerted bullying, as well.

From those students who participated in a school mediation programme and have suffered bullying, $62 \%$ chose to talk to their friends about it and $38 \%$ to their teachers (nobody to their parents). Similarly, from the students who did not participate in a programme, $60 \%$ chose to talk about it to their parents (only $20 \%$ to their friends and $20 \%$ to their teachers). At the same time, the students who have exerted bullying stated in their majority that neither their teachers $(75 \%)$ nor their parents $(55 \%)$ have discussed about it with them.

\subsection{The Role of Adults and Classmates}

There was a correlation between the participation in a school mediation programme and the opinion of students on the role of teachers in bullying incidents $\left(\chi^{2}(2, \mathrm{~N}=110)=8.120, \mathrm{p}=0.017\right)$. In particular (Table $3)$, without any gender differentiation observed, those who participated in a school mediation programme were more critical (only $36.1 \%$ of them thought that teachers were almost always trying to stop incidents of in-school violence and bullying) in relation to those students who did not participate in a corresponding programme $(63.3 \%)$.

\begin{tabular}{|c|c|c|c|c|c|}
\hline \multirow{2}{*}{$\begin{array}{l}\text { Participation in } \\
\text { a school } \\
\text { mediation } \\
\text { programme }\end{array}$} & \multirow[b]{2}{*}{ Number of students } & \multicolumn{4}{|c|}{ Frequency of teachers' intervention in bullying incidents } \\
\hline & & $\begin{array}{l}\text { Almost never } \\
\text { /occasionally }\end{array}$ & Sometimes /often & Always & Totals \\
\hline \multirow{3}{*}{ YES } & Absolute & 10 & 29 & 22 & 61 \\
\hline & $\%$ of participants & 16.4 & 47.5 & 36.1 & 100 \\
\hline & $\%$ of total & 9.1 & 26.4 & 20.0 & 55.5 \\
\hline \multirow[b]{2}{*}{ NO } & Absolute & 4 & 14 & 31 & 49 \\
\hline & $\begin{array}{l}\% \text { of non- } \\
\text { participants }\end{array}$ & 8.2 & 28.6 & 63.3 & 100 \\
\hline \multirow{3}{*}{ Totals } & $\%$ of total & 3.6 & 12.7 & 28.2 & 44.5 \\
\hline & Absolute & 14 & 43 & 53 & 110 \\
\hline & $\%$ & 12.7 & 39.1 & 48.2 & 100 \\
\hline
\end{tabular}

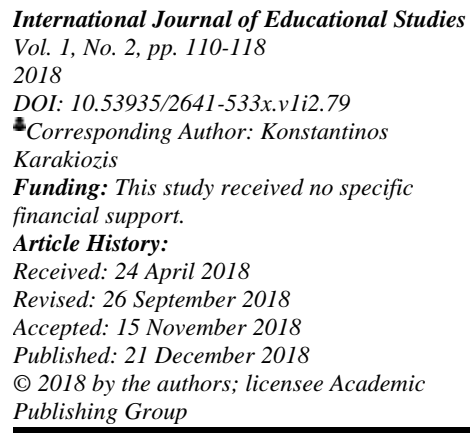

Similar differentiation was also observed regarding the role of peers in incidents of in-school violence and bullying. In particular, $13.6 \%$ of those boys who did not participate in a mediation programme $(14.3 \%$ of total) felt that their classmates were almost always intervened in incidents of in-school violence and bullying. On the contrary, for those students who participated in a mediation programme, the equivalent figure was $6.6 \%$ (3\% for girls and $10.7 \%$ for boys). There is a correlation between the participation of students in a school mediation programme and the degree of their reaction towards a bullying incident $\left(\chi^{2}(4, \mathrm{~N}=110)=\right.$ 
$16.318, \mathrm{p}=0.003)$. In particular, $75.5 \%$ of those participating in a school mediation programme, and only $37.7 \%$ of those who did not, stated that they were trying to help ( $61.7 \%$ of girls and $46 \%$ of boys). Instead, $27.9 \%$ of those who did not participate in a mediation programme and $14.3 \%$ of those participating stated that they had not noticed any cases of in-school violence and bullying. Finally, $26.5 \%$ of participants in a mediation programme and $13.1 \%$ of non-participants stated that they were very likely to have aggressive behavior.

\subsection{Attitudes of Students Participating in a School Mediation Programme}

The vast majority of students participating in school mediation programmes considered that it contributed mainly to (Table 4):

- The communication between students (a lot for $63 \%$ of boys and $33 \%$ of girls);

- The collaboration among students (a lot or enough for $88 \%$ of students);

- Assist intimidated schoolmates (a lot or enough for $88 \%$ of students);

- The recognition of the feelings of students (a lot for $53 \%$ of girls and $20 \%$ of boys);

- The ability of "listening" to others (a lot for $47 \%$ of girls and $27 \%$ of boys);

- The inclusion of students in a group (a lot or enough for $72 \%$ of students).

Table- 4. Contribution of the school mediation programme, according to the students' opinion.

\begin{tabular}{|c|c|c|c|c|c|c|}
\hline Contribution & 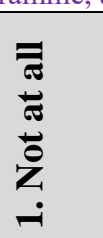 & i & ம & 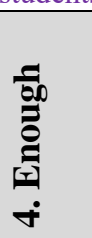 & $\begin{array}{l}\overrightarrow{0} \\
\dot{a} \\
\text { in }\end{array}$ & $\begin{array}{l}\frac{n}{\pi} \\
\stackrel{5}{0} \\
\end{array}$ \\
\hline Communication between students \% & 0 & 2.0 & 4.0 & 40.0 & 54.0 & 100 \\
\hline Collaboration among students $\%$ & 0 & 0 & 12.0 & 38.0 & 50.0 & 100 \\
\hline Assist intimidated schoolmates \% & 0 & 0 & 12.0 & 38.0 & 50.0 & 100 \\
\hline Recognition of feelings \% & 0 & 6.0 & 16.0 & 40.0 & 38.0 & 100 \\
\hline Ability of "listening" \% & 0 & 0 & 10.0 & 34.0 & 56.0 & 100 \\
\hline Inclusion of students in a group $\%$ & 2.0 & 4.0 & 22.0 & 30.0 & 42.0 & 100 \\
\hline Having fun $\%$ & 10.0 & 14.0 & 12.0 & 24.0 & 40.0 & 100 \\
\hline Having confidence among schoolmates & 2.0 & 6.0 & 20.0 & 36.0 & 36.0 & 100 \\
\hline Emotional management $\%$ & 2.0 & 6.0 & 26.0 & 24.0 & 42.0 & 100 \\
\hline
\end{tabular}

Finally, according to the students participating in school mediation programmes, the greatest benefits that school derived from these programmes are (Table 5):

- The reduction of incidents of in-school violence and bullying (very likely for $49 \%$ of boys and $29 \%$ of girls);

- A better cooperation among students and teachers (very likely for $42 \%$ of girls and $26 \%$ of boys);

- $\quad$ The compliance with school rules (likely enough for $53 \%$ of boys and $32 \%$ of girls);

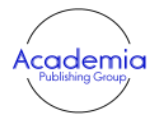

International Journal of Educational Studies Vol. 1, No. 2, pp. 110-118

2018

DOI: 10.53935/2641-533x.v1i2.79

Corresponding Author: Konstantinos

Karakiozis

Funding: This study received no specific

financial support.

Received: 24 April 2018

Revised: 26 September 2018

Accepted: 15 November 2018

Published: 21 December 2018

(C) 2018 by the authors; licensee Academic

Publishing Group
- $\quad$ Reducing violent behaviors at school (very likely for $21 \%$ of girls and $40 \%$ of boys);

- $\quad$ Assumption of responsibility by students.

Table- 5. Possible benefits of the school from implementing a school mediation programme.

\begin{tabular}{|c|c|c|c|c|c|c|}
\hline Possible benefits & 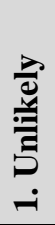 & 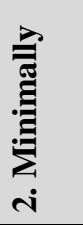 & $\begin{array}{l}\frac{\lambda}{0} \\
\frac{0}{\pi} \\
\frac{0}{0} \\
\frac{0}{0} \\
\dot{0} \\
\dot{0}\end{array}$ & 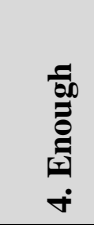 & 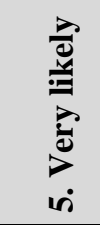 & $\frac{\mathscr{n}}{\tilde{J}}$ \\
\hline Reduction of school bullying \% & 0 & 8.82 & 11.76 & 47.06 & 32.35 & 100 \\
\hline Students' and teachers' collaboration \% & 0 & 5.88 & 11.76 & 47.06 & 35.30 & 100 \\
\hline Compliance with school rules $\%$ & 0 & 8.82 & 26.47 & 41.18 & 23.53 & 100 \\
\hline Reducing violent behaviors at school \% & 0 & 5.88 & 17.65 & 47.06 & 29.41 & 100 \\
\hline Assumption of responsibility by students $\%$ & 0 & 2.94 & 26.47 & 26.47 & 44.12 & 100 \\
\hline
\end{tabular}


In the responses of students participating in a school mediation programme, correlations are observed in the following variables:

- The frequency of exerting bullying by students is associated with recognizing the contribution of the programme to improving listening ability $(\mathrm{r}=0.41, \mathrm{p}=015, \mathrm{~N}=50)$;

- The recognition of students assuming responsibilities is associated with students' and teachers' collaboration

$(\mathrm{r}=0.52, \mathrm{p}=000, \mathrm{~N}=49)$ and the reduction of violent behaviors at school $(\mathrm{r}=0.54, \mathrm{p}=000, \mathrm{~N}=48)$;

- Students' and teachers' collaboration is correlated with school rule compliance $(r=0.60, p=000, N=$ 49) and assumption of responsibility by students $(\mathrm{r}=0.52, \mathrm{p}=$ $000, \mathrm{~N}=49$ );

- The compliance with school rules is correlated with the reduction of in-school violence and bullying incidents $(\mathrm{r}=0.63, \mathrm{p}=000, \mathrm{~N}=49)$, with students' and teachers' collaboration $(\mathrm{r}=0.60, \mathrm{p}=000, \mathrm{~N}=$ $49)$; with reducing violent behaviors at school $(\mathrm{r}=0.54, \mathrm{p}=000, \mathrm{~N}=48)$ and with the assumption of responsibility by students $(\mathrm{r}=0.61, \mathrm{p}=000, \mathrm{~N}=49)$.

\section{Discussion}

Regarding the students' opinion on the role of adults in incidents of in-school violence and bullying (Table 3), there is relevance to the results of other surveys, where one out of three students considered teachers' intervention as non-systematic (Psalti \& Konstantinou, 2007). In addition, a limited number of students is observed who have exerted or suffered bullying and choose to discuss it with an adult (Pateraki \& Houndoumadi, 2001). These data along with the relevant bibliography (Andreou, Didaskalou, \& Vlachou, 2007; European Anti-Bullying Network, 2014; Katsigianni, 2006; Kokkevi, Stavrou, Kanavou, \& Fotiou, 2015; Kokkevi, Xanthaki, Fotiou, \& Kanavou, 2012; Ministry of Education, 2016; Olweus., 2005; Psalti \& Konstantinou, 2007; Smile of the Child, 2012; Tsiantis et al., 2008) lead us to the conclusion that the phenomenon of in-school violence and bullying is greatly influenced by the behaviors and attitudes of all members of the school community (students, observers, teachers, parents, intimidated or intimidating students). To address these incidents, the development of social skills is proposed, among other things, such as the empathy for all students, especially those who exert in-school violence and bullying (Coleman, 2011; Rigby., 2012).

The main element that differentiates students participating in a school mediation programme from the rest of them is the awareness of incidents of in-school violence and bullying. It is typical that almost twice as many (three out of four) stated they try to help one of their classmates. On the other hand, the participation in a school mediation programme is associated with students' attitudes towards the role of adults in incidents of in-school violence and bullying, as also observed in a previous research (Karakiozis et al., 2015a).

Both in this research and in bibliography (Andreou et al., 2007; Artinopoulou, 2010; Katsigianni, 2006; Kokkevi et al., 2015; Kokkevi et al., 2012; Olweus., 2005; Psalti \& Konstantinou, 2007; Smile of the Child, 2012; Tsiantis et al., 2008) there are substantial differences observed in the attitudes of both sexes towards incidents of in- school violence and bullying as well as school mediation programmes. In particular:

- boys, in a much larger percentage than girls, suffer but mainly exert bullying (Andreou et al., 2007; Artinopoulou, 2010; Katsigianni, 2006; Kokkevi et al., 2015; Kokkevi et al., 2012; Ministry of Education, 2016; Olweus., 2005; Psalti \& Konstantinou, 2007; Smile of the Child, 2012; Tsiantis et al., 2008);

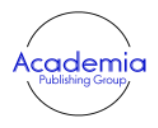

International Journal of Educational Studies Vol. 1, No. 2, pp. 110-118 2018

DOI: $10.53935 / 2641-533 x . v 1 i 2.79$

"Corresponding Author: Konstantinos Karakiozis

Karakiozis

Funding: This study
financial support.

Article History:

Received: 24 April 2018

Revised: 26 September 2018

Accepted: 15 November 2018

Published: 21 December 2018

(C) 2018 by the authors; licensee Academic Publishing Group
- a higher percentage of girls want to help in incidents of in-school violence and bullying (Artinopoulou, 2010; Olweus.. 2009; Psalti \& Konstantinou, 2007);

- boys evaluate different elements as positive, in a school mediation programme, than girls; i.e., boys consider communication, having fun, reducing incidents of in-school violence and bullying, compliance with school rules and reducing violent behavior as more important; in contrast, girls consider as more important the recognition of feelings, the ability to listen, trust and better collaboration of students and teachers.

These differences suggest, in line with other surveys, to a great extent a different way of thinking and a different level of emotional maturity between the two sexes (Coleman, 2011).

The main results, according to the present research and the related bibliography, regarding the implementation of school mediation programmes include:

- The development of the social and communication skills of the students (Bitel \& Rolls, 2000; Flecknoe, 
2005; Noaks \& Noaks, 2009) their inclusion into the school environment (Lindsay, 1998) and the improvement of their ability to resolve conflicts non-violently (Bickmore, 2002). Particular emphasis is put by the participants to the ability to listen, the communication or collaboration between students and the help to their classmates (Tables 4-5). Also, the increased participation of students from large families and the difficulty of those who have suffered bullying and participated in a programme to discuss it with their parents can not be ignored.

- The development of a sense of responsibility (Bitel \& Rolls, 2000) and the development of a collaboration climate and a mutual assistance attitude among students (Tables 4-5). These elements contribute to the improvement of the self-respect students (Bitel \& Rolls, 2000; Burrell et al., 2003) and the moulding of their personality in terms of autonomy and accountability (Bitel \& Rolls, 2000; Burrell et al., 2003; Flecknoe, 2005; Noaks \& Noaks, 2009).

- Finally, at school level the benefits include (Tables 4-5) the reduction of conflicts and bullying incidents(Bickmore, 2002; Flecknoe, 2005; Lindsay, 1998; Noaks \& Noaks, 2009) and the improvement of the school climate (Burrell et al., 2003; Flecknoe, 2005; Noaks \& Noaks, 2009).

\subsection{Restrictions}

The current research planning is subject to a number of limitations due to:

- The inability to control the environment (Kyriazi, 1998) because of the absence of a single educational

- Programme in school mediation and the implementation of parallel actions by schools;

- The self-reporting of bullying incidents;

- The attitudes of teachers who are not involved in the mediation programme, of the two out of three head- masters of the schools (in the sample) and of the students' parents have not been recorded.

The attitude of teachers who implemented the specific mediation programmes have been recorded in another survey, which the results of are still being processed.

\section{Conclusion}

School mediation programmes are based on a structured dynamic process and are a credible alternative to conflict management. They contribute, among other things, to activating students, taking responsibility, developing their social skills and improving the school climate. The positive response of the students participating in these programmes voluntarily and beyond ordinary school hours is an important step and a guide for a school closest to the interests and needs of students, although without being a panacea.

\section{References}

Andreou, E., Didaskalou, E., \& Vlachou, A. (2007). Evaluating the effectiveness of a curriculum-based anti-bullying intervention program in Greek primary schools. Educational Psychology, 27(5), 693-711.Available at: https://doi.org/10.1080/01443410601159993.

Artinopoulou, V. (2010). School mediation. Educating students in the management of violence and bullying. Athens: Nomiki Vivliothiki.

Association for Conflict Resolution Education Section. (2007). Recommended standards for school-based peer mediation programs. Washington, DC: Association for Conflict Resolution.

Bauer, N. S., Lozano, P., \& Rivara, F. P. (2007). The effectiveness of the Olweus bullying prevention program in public middle schools: A controlled trial. Journal of Adolescent Health, 40(3), 266-274.Available at: https://doi.org/10.1016/j.jadohealth.2006.10.005.

Bickmore, K. (2002). Peer mediation training and program implementation in elementary schools: Research results. Conflict Resolution Quarterly, 20(2), 137-160.Available at: https://doi.org/10.1002/crq.17.

International Journal of Educational Studies Vol. 1, No. 2, pp. 110-118

2018

DOI: $10.53935 / 2641-533 x . v 1 i 2.79$

Corresponding Author: Konstantinos

Karakiozis

Funding: This study received no specific

financial support.

Article History:

Received: 24 April 2018

Revised: 26 September 2018

Accepted: 15 November 2018

Published: 21 December 2018

() 2018 by the authors; licensee Academic Publishing Group

Bitel, M., \& Rolls, D. (2000). Mediation in a South London secondary school. In M. Liebmann (Ed.), Mediation in context (pp. 6984). London: Jessica Kingsley Publishers.

Black, S. A., \& Jackson, E. (2007). Using bullying incident density to evaluate the Olweus bullying prevention programme. School Psychology International, 28(5), 623-638.Available at: https://doi.org/10.1177/0143034307085662.

Burrell, N. A., Zirbel, C. S., \& Allen, M. (2003). Evaluating peer mediation outcomes in educational settings: A meta-analytic review. Conflict Resolution Quarterly, 21(1), 7-26.Available at: https://doi.org/10.1002/crq.46.

Center for European Constitutional Law. (2015). Material for educational staff and educators". Deliverable 1.1. Project: "Creation of training educational informative material and training curriculum". Themistocles and dimitris tsatsos foundation, Chapter 10 , "School mediation: Training students to manage school bullying. Athens.

Cohen, L., \& Manion, L. (1994). Methodology of educational research (translated into Greek by C. Mitsopoulou and M. Filopoulou). Athens: Metaichmio. 
Coleman, J. (2011). Psychology of adolescent age (translated into Greek by H.G.. Bezevegkis). Athens: Gutenberg.

Cremin, H. (2007). Peer mediation: Citizenship and social inclusion revisited. Buckingham: Open University Press.

Creswell, J. W. (2011). Research in education: designing, conducting and evaluating quantitative and qualitative research. Athens: Ellin.

European Anti-Bullying Network. (2014). European guide of anti-bullying good practices. In Daphne iii programme: European commission.

Farrington, D. P., \& Ttofi, M. M. (2009). How to reduce school bullying. Victims and Offenders, 4(4), 321-326.Available at: https://doi.org/10.1080/15564880903227255.

Flecknoe, M. (2005). What does anyone know about peer mediation?®. Improving Schools, 8(3), 221-235.Available at: https://doi.org/10.1177/1365480205060437.

Galanaki, E. (2010). School bullying: How effective are interventions? Paper presented at the Proceedings of the 5th Panhellenic Conference on "Learning how to Learn. Hellenic Institute of Applied Pedagogics and Training (ELLIEPEK): Athens.

General Census. (2011). Hellenic statistical authority (ELSTAT). Retrieved from http://www.statistics.gr/2011-census-pop-hous.

Giannatou, A. (2011). The operation of a group of ,peer mediators. Paper presented at the 2nd Gymnasium of Aspropyrgos. In T. Thanos (ed.), Mediation in School and Society. Remedial Justice, School Mediation, Penal Conciliation. Pedio: Athens.

Gollwitzer, M., Eisenbach, K., Atria, M., Strohmeier, D., \& Banse, R. (2006). Evaluation of aggression-reducing effects of the "Viennese social competence training". Swiss Journal of Psychology, 65(2), 125-135.Available at: https://doi.org/10.1024/1421-0185.65.2.125.

Haynes, J. M., Haynes, G. L., \& Fong, L. S. (2004). Principles of broad-based mediation practice. In Mediation: Positive conflict management (pp. 1-22): State University of New York Press.

Johnson, D. W., \& Johnson, R. T. (1996). Conflict resolution and peer mediation programs in elementary and secondary schools: A review of the research. Review of Educational Research, 66(4), 459-506.Available at: https://doi.org/10.3102/00346543066004459.

Karakiozis, K., Papapanousi, C., Mavrakis, A., \& Papakitsos, E. C. (2015b). Initiating an Olweus-based intervention against schoolbullying. Journal of Social Sciences and Humanities, 1(3), 173-179.

Karakiozis, K., Papapanousi, C., Papakitsos, E., \& Argyriou, A. (2015a). Recording the opinion of students about the attitude of adults in school-bullying. International Journal of Academic Research in Progressive Education and Development, 4(1), 178189.Available at: https://doi.org/10.6007/ijarped/v4-i1/1652.

Katsigianni, L. V. (2006). The phenomenon of bullying at primary school. Doctoral Thesis University of the Aegean.

Kokkevi, A., Stavrou, M., Kanavou, E., \& Fotiou, A. (2015). Adolescents in school environment. In series of thematic issues: Teens, Behaviors \& Health. Athens: University Research Institute for Mental Health.

Kokkevi, A., Xanthaki, M., Fotiou, A., \& Kanavou, E. (2012). Adolescents in Greece compared to their peers in the HBSC 2010 research countries. In Series of thematic issues: Teens, Behaviors \& Health. Athens: University Research Institute for Mental Health.

Kyriakides, L., Kaloyirou, C., \& Lindsay, G. (2006). An analysis of the revised olweus bully/victim questionnaire using the rasch measurement model. British Journal of Educational Psychology, 76(4), 781-801.Available at: https://doi.org/10.1348/000709905x53499.

Kyriazi, N. (1998). Sociological research, critical review of methods and techniques. Athens: Greek Scientific Publications.

Liebmann, M. (2000). Mediation in context. London: Jessica Kingsley Publishers.

Lindsay, P. (1998). Conflict resolution and peer mediation in public schools: What works? Mediation Quarterly, 16(1), 8599. Available at: https://doi.org/10.1002/crq.3890160109.

Ministry of Education. (2016). Pan-hellenic survey on in-school violence and bullying in primary and secondary education. Retrieved from https://www.minedu.gov.gr/publications/docs2016/08_03_16_ereyna_bulling.doc.

Noaks, J., \& Noaks, L. (2009). School-based peer mediation as a strategy for social inclusion. Pastoral care in Education, 27(1), 5361.Available at: https://doi.org/10.1080/02643940902731880.

Observatory. (2017). School dropout in Greek primary and secondary education. Reference period 2013-2016. IEP, Observatory on issues of recording and coping with school dropout: Athens.

Olweus, D. (1997). Bully/victim problems in school: Knowledge base and an effective intervention program. The Irish Journal of Psychology, 18(2), 170-190.Available at: https://doi.org/10.1080/03033910.1997.10558138.

Olweus., D. (2005). A useful evaluation design, and effects of the Olweus bullying prevention program. Psychology, Crime \& Law, 11(4), 389-402.Available at: https://doi.org/10.1080/10683160500255471.

Olweus.., D. (2009). Bullying and violence at school. What we know and what can we do (translated into Greek by E. Markozane from the original edition of 1993). Athens: Society for Psychosocial Health of the Child and the Adolescent.

Panousis, I. (2011). Conflicts and crisis management at school. In T. Thanos (ed.), Mediation in school and society. Remedial justice, school mediation, penal conciliation (pp. 29-38). Athens: Pedio.

Papavasileiou, H., \& Mavrakis, A. (2013). Environmental education: Issue water: Different approaches in secondary general and technical lyceum in a social and environmental stressed area in Greece. Procedia Technology, 8, 171-174.Available at: https://doi.org/10.1016/j.protcy.2013.11.024

Pateraki, L., \& Houndoumadi, A. (2001). Bullying among primary school children in Athens, Greece. Educational Psychology, 21(2), $167-175$.

Pellegrini, A. D. (2001). Sampling instances of victimization in middle school: A methodological comparison. In J. Juvonen and S. Graham (Eds.), Peer Harassment in School: The Plight of the Vulnerable and Victimized. (pp. 125-144). New York / London: The Guilford Press.

Received: 24 April 2018

Revised: 26 September 2018

Accepted: 15 November 2018

Published: 21 December 2018

() 2018 by the authors; licensee Academic

Publishing Group 
Peripheral Unity of Western Attica. (2015). Strategic plan of western attica 2020+ for public consultation. Retrieved from http://www.patt.gov.gr/site/index.php?option=com content\&view=article\&id=15005:dytiki-attiki-2020-sxedio-stratigikoysxediasmoy-pros-diavoylefsi\&catid=288\&Itemid=305.

Psalti, A., \& Konstantinou, K. (2007). The phenomenon of bullying in the schools of secondary education. Psychology, 14(4), 329345.

Rigby, K. (2008). School bullying modern views (translated into Greek by V. Dobola from the original edition of 2002). Athens: Topos (Motivo Publishing).

Rigby., K. (2012). Bullying interventions in schools: Six basic approaches. Boston: Wiley.

Salvati, L., \& Mavrakis, A. (2014). Narrative and quantitative analysis of human pressure, land-use and climate aridity in a transforming industrial basin in Greece. International Journal of Environmental Research, 8(1), 115-122.

Smile of the Child. (2012). European research on the phenomenon of school bullying. In DAPHNE III: Final report on "Europe's antibullying campaign project. Retrieved from http://www.e-abc.eu/files/1/PDF/Research/School_Bullying_Greek.pdf.

Solberg, M. E., \& Olweus, D. (2003). Prevalence estimation of school bullying with the Olweus Bully/Victim Questionnaire. Aggressive Behavior: Official Journal of the International Society for Research on Aggression, 29(3), 239-268.

Stitt, A. J. (2004). Mediation: A practical guide. London: Cavendish Publishing Limited.

Tsiantis, G., Asimopoulos, C., Chatzipemos, T., Soumaki, E., Diareme, S., \& Giannakopoulou, D. (2008). The phenomenon of bullying at primary school. Child and Adolescent - Mental Health and Psychopathology, 10(1), 97-100.

U.S. Department of Justice. (2000). Want to resolve a dispute? Try mediation. In Youth in action. Washington, DC. 15: Office of Juvenile Justice and Delinquency Prevention.

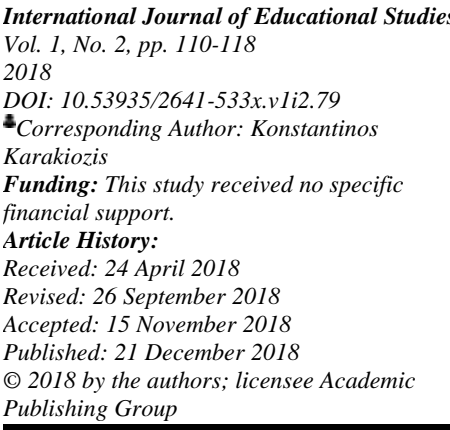

